\title{
InVESTigating STUdent SATisfaction IN Remote Online Learning Settings During COVID-19 IN INDONESIA
}

\author{
Jenny Ngo ${ }^{a}$ \\ Institut Sains dan Teknologi Terpadu Surabaya \\ Budiyono \\ Agustinus Ngadiman \\ Universitas Katolik Widya Mandala Surabaya
}

\begin{abstract}
This study was to examine student satisfaction in remote online learning environments during COVID-19 in Indonesia. The participants were 65 undergraduate Informatics students from a private university in Surabaya, Indonesia. Data from Strachota's Student Satisfaction survey responses were examined using quantitative analyses. According to the findings, there was a strong and statistically significant relationship between student satisfaction and interaction. According to predictive models, every type of interaction could predict student satisfaction, with student interaction with content being the most powerful predictor. Furthermore, the findings revealed that self-ability in digital learning, good internet accessibility and connectivity, the presence and feedback of the teacher, website content, and the ability to learn from peer feedback and group discussions all played important roles in influencing student satisfaction. Students reported that they were generally more satisfied with their improved spoken communication skills, which helped them achieve their learning objectives. The findings suggest that integrating synchronous and asynchronous learning effectively promotes student learning and improves student satisfaction in Indonesia's remote online learning environment.
\end{abstract}

Keywords: COVID-19; interaction; Indonesia; remote online learning; satisfaction

\section{Introduction}

Indonesia is the world's largest archipelago country. It consists of over 1,700 islands, including five main ones: Sumatra, Sulawesi, Kalimantan, Java (populated), and Irian Jaya, and has a population of over 270 million people (World Bank, 2021). Currently, Indonesia has 4.593 higher education institutions "(a 0.01 percent decrease from the previous year due to the data update process and the improvement in higher education quality)" (PDDikti Kemendikbud, 2020, p. 4).

The year 2020 marks a crisis moment in Indonesia's higher education system, ushering in fundamental changes. The first COVID-19 cases were discovered in Jakarta, Indonesia, in early March 2020. The Indonesian government then issued Circular Letter No. 36962/MPK.A/HK/2020 on March 17, 2020, announcing online learning and working from home to control the spread of COVID-19, promoting social distancing prevent excessive/mass gatherings at educational institutions (Kemendikbud, 2020a). As of March 24, 2020, the national declaration required 4.593 higher education institutions under the Ministry of Education and Culture, affecting 8,483,213 students

Correspondence can be directed to: jennyngo@istts.ac.id 
and 312,890 lecturers (PDDikti Kemendikbud, 2020), to adopt remote online learning with the use of internet technology to replace most, if not all, face-to-face classrooms with no or little preparation (Kusnayat, Muiz, Sumarni, Mansyur, \& Zaqiah, 2020; Siahaan, 2020).

Remote online learning is novel in the context of higher education in Indonesia. Remote online learning refers to learning and teaching processes that take place entirely online and are mediated by the internet across Indonesia's geographical spreads. Its implementation is not impossible, but it is extremely challenging. First, most lecturers have little or no experience with online education (Kusnayat et al., 2020; Siahaan, 2020). Because of the crisis, they were forced to transition from faceto-face to online education in a quick and unexpected manner. As a result of the mandated use of completely remote online teaching and learning for continuing education, various issues with lesson materials, content courses, and teaching methods using e-learning platforms and the internet have arisen (Kusnayat et al., 2020; Siahaan, 2020). Second, the affordability and accessibility of the internet are critical in providing remote online learning experiences comparable to face-to-face courses. Video conferencing applications, such as Zoom video meetings, Google Meet, and Microsoft Teams require a fast internet connection to enable online learning at a distance. This phenomenon, in most cases, did not occur everywhere in Indonesia. The most significant challenges were network instabilities and audio loss (Firman \& Rachman, 2020). Consequently, online learning became fragmented, necessitating students or educators to leave the classroom and reconnect. Third, Indonesia's high cost of internet data packages (quotas) has become a major impediment to remote education. According to CNN Indonesia, "data usage for video conferencing using the zoom application with $720 \mathrm{p}$ video quality for one hour consumes $540 \mathrm{MB}$ of data, and in Indonesia, the price of a $1 \mathrm{~GB}$ quota costs 20 thousand to 50 thousand rupiahs" (cited in Firman \& Rachman, 2020, p. 83). Firman and Rachman (2020) estimate that "if one student has eight online courses, each of which uses the Zoom video conferencing application for at least one hour every week, the student will spend 80 to 200 thousand rupiahs (between 5 and 14 US dollars, currency rate on July 12 2021) per week, depending on the cellular providers used" (pp. 83-84). In response to the internet's accessibility and affordability, the Indonesian government, through the Ministry of Education and Culture, has provided $50 \mathrm{~GB}$ of free internet data to all university students and lecturers in Indonesia from September to December 2020 (Kemendikbud, 2020b) and 15 GB of free internet data from January to May 2021 (Kemendikbud, 2021). Fourth, students face some emotional and mental health risks as a result of remote online learning. Students want to be emotionally present with their classmates and friends. Still, due to the pandemic, they are unable to make physical contacts and build relationships as they would face-to-face. "Early indications in the COVID19 context indicate that more than one-third of adolescents report high levels of loneliness and almost half of 18- to 24-year old are lonely during lockdown" (Loades et al., 2020, p. 1218). Loneliness and social isolation increased the likelihood of developing mental illnesses such as depression (Loades et al., 2020). Additional stressors identified by Indonesian students include a large amount of homework, class assignments, and projects (Kusnayat et al., 2020; Siahaan, 2020). Indonesian educators who have been placed in a new learning environment have difficulty adjusting to remote learning programs. As a result, in order to keep the learning processes running smoothly, they assigned a lot of homework, class tasks, and projects to the students (Kusnayat et al., 2020; Siahaan, 2020).

Despite the fact that remote online learning proved to be a useful and practical tool for sustaining educational delivery during the covid-19 pandemic, some questions have been raised about the success of remote online learning in Indonesian higher education due to the issues above. In this regard, higher education institutions believe that student satisfaction is an important factor in determining the success of their programs (Yekselturk \& Yildirim, 2008; Kuo, Walker, Belland, \& Schroder, 2014). According to Yekselturk and Yildirim (2008), "student satisfaction is seen as one of the key variables in determining the success or failure of distance learners, courses, and programs in the literature" (p. 51).

Scholars have identified interaction as one of the most important drivers of student satisfaction over the last decade. Sher (2009) discovered that student-instructor interaction and student-student 
interaction were strongly predictive of student satisfaction in a study of 208 higher education students in the United States. Ahn (2012) investigated the impact of learning interaction on student satisfaction with $100 \%$ online courses in the department of learning technologies in North Texas, USA. Based on 159 responses, Ahn (2012) discovered that learner-content and learner-instructor were significant predictors of student satisfaction. Kuo, Walker, Belland, and Schroder (2014) discovered that learner-instructor interaction, learner-content interaction, and internet self-efficacy contributed to student satisfaction in a study involving 102 students at Western University in the United States. From these studies, we learn that "interaction is an important part of learner satisfaction" (Yekselturk \& Yildirim, 2008, p. 52).

This study aimed to determine the relationship between interaction and student satisfaction in a remote online learning environment during COVID-19 in Indonesia. The remainder of the study is organized as follows in order to produce meaningful results. To begin, a review of the existing literature is provided. The research questions are then presented. Next, the research methodologies, including participants and procedures and data analysis, are described. Following that, the empirical findings are presented and discussed. Finally, the study's findings and practical implications are discussed.

\section{Remote Online Learning}

Remote online learning is a type of blended online learning that higher education institutions are implementing in response to the COVID-19 pandemic. In actuality, the novelty of blended learning is defined as "the blending of face-to-face instruction with various types of non-classroom technologymediated delivery, [which] has been practiced within the academy for more than four decades" (Dziuban et al., 2004, p. 2). Its concept combines traditional classroom instruction with the advantages of Information Communication Technology (ICT)-supported learning, which includes both offline and online learning. In addition, blended learning allows for collaborative learning, constructive learning, and computer-assisted learning (Lalima \& Dangwal, 2017). In other words, blended learning is an instructional model that "focuses on student-centered instruction and increases interaction between student-instructor, student-student, student content, and student-outside resources" (Dziuban et al., 2004, p.3). This type of learning has maintained "higher levels of student and faculty satisfaction [and] student learning outcomes" when compared to traditional courses (Dziuban et al., 2004, p. 3).

Remote online learning as a pandemic response is defined in this study as a combination of synchronous and asynchronous instruction (Harasim, 1989) in which teachers and students are separated by geographical distance for all or most of the time they teach and learn (Moore \& Kearsley, 1996) and must rely on communication technologies (Allen \& Seaman, 2010). It defines the online teaching and learning process, which includes direct instruction, indirect instruction, collaborative teaching and learning, and individualized computer-assisted learning (Lalima \& Dangwal, 2017). Direct instruction, also known as synchronous instruction, is a form of communication in which students interact with the lecturer and their classmates at the same time via Web-videoconferencing (Fatani, 2020). Synchronous communication tools enable learners and instructors to interact directly and provide feedback (Giesbers et al., 2013), beneficial to the teaching-learning process. It is extremely motivating for teachers and students because it adds a virtual human touch to the teaching and learning process (Lalima \& Dangwal, 2017). Synchronous classrooms allow students to interact with teachers and allow students to engage in discussions with their classmates about various aspects of the course content and exchange ideas (Dziuban et al., 2018). Students gain confidence as a result of this and critical thinking and problem-solving abilities (Speece, 2012; Foerderer et al., 2021).

Indirect instruction, also known as asynchronous instruction, is a type of communication in which students communicate with the teacher and classmates at different times through e-learning platforms. Asynchronous discussion boards allow a large number of students to participate and interact with one another on a specific topic (Corfman \& Beck, 2019). They provide students with indirect interaction with their course content in a variety of interesting and versatile ways (Lalima 
\& Dangwal, 2017). Along with teacher-developed online materials, asynchronous discussion boards are frequently used as a central component of courses (Corfman \& Beck, 2019).

Both synchronous and asynchronous instructions in remote online learning rely heavily on the internet and e-learning platforms for student interaction with the teacher, classmates, and course content (Yukselturk \& Yildirim, 2008; Hillman, Willis, \& Gunawardena, 1994). Various applications such as web-video conferencing (Fatani, 2020), Edmodo learning platform (Ngo \& Ngadiman, 2019), WhatsApp (So, 2016), Facebook and Instagram (Kumar \& Nanda, 2019) can support the implementation of remote online learning. As a result, owning digital devices (e.g., a laptop, a personal desktop, or a smartphone), a fast and stable internet connection, and an affordable WIFI or data package are critical in online learning delivery, particularly in the Indonesian context (Firman \& Rachman, 2020).

In this study, remote online learning is a type of teaching and learning environment in which 1 ) the student is physically separated from the lecturer, 2) the student accesses learning materials through asynchronous learning resources (Edmodo), and 3) the student interacts with the teacher and other students through synchronous web-video conferencing apps (zoom). In short, the remote online course provided both synchronous and asynchronous instruction, completely replacing faceto-face learning by allowing students to connect with their lecturer, other students, and course content while the lecturer monitors students' learning processes.

According to Jiang, Islam, Gu, and Spector (2021), student satisfaction is extremely important in online learning. Satisfaction is a pleasant sensation or positive emotion that people feel due to comparing their perceptions and experiences of the service they are receiving to what they expect (Ahn, 2012). Learning satisfaction is the value that students place on their educational experience, and it is one of the most important factors to consider when assessing the efficacy of online learning (Kuo et al., 2014; Alqurashi, 2019). This study defines student satisfaction as students' positive feelings about their engagement with course content, teachers, peers, and technology in a remote online learning setting. In addition, students are satisfied with remote online learning if they believe the course has helped them improve their spoken communication skills and addressed their learning needs.

\section{Interaction}

Interaction is regarded as an important component in achieving online learning goals. Moore (1989) defines it as having three critical dimensions: student-to-content, student-to-teacher, and studentto-student. Moore's conceptual framework was expanded to include interaction between students and technology (Hillman, Willis, \& Gunawardena, 1994). Individual students intellectually elaborating and reflecting on the subject matter or course content are involved in student-content interaction (Moore, 1989). According to Moore and Kearsley (1996), the most fundamental interaction in online education is student-content interaction. Any document files, audio files, video files, and/or websites used to deliver online learning are referred to as course content. When students engage in course content that is posted or distributed online via e-learning platforms, they will have some time for reflection and will be able to develop their understanding of what they read, listen to, and watch at any time and from any location (Moore, 1989; Anderson, 2003). This type of interaction expands and sharpens students' knowledge through thinking, reasoning, and problem solving (Moore \& Kearsley, 1996). "Only when instructional content is meaningful and relevant can learning occur" (Ahn, 2012, p. 6). As a result, the course design is critical in persuading students' learning and satisfaction through their course expectations (Lin et al., 2008).

Student-teacher interaction is two-way communication between a teacher and students based on the exchange of subject-matter information (Moore, 1989). It emphasizes the learning process when the teacher effectively delivers the course, provides feedback, encourages and supports students to actively participate in the classrooms (Moore, 1989), and influences students to do better in their studies (Gopal et al., 2021). According to Croxton (2014), a primary determinant of 
student satisfaction is the quality and consistency of student-teacher communication. Furthermore, Roger (1992) stated that using instructor feedback as a self-evaluation tool for students can help them improve their performance (as cited in Gopal et al., 2021). Ivankova and Stick (2007) and Ngo and Ngadiman (2019) have noted the importance of feedback on student learning, performance, and satisfaction.

Student-student interaction is defined as mutual or social contact between or among students who collaborate and exchange information, knowledge, opinions, or ideas about the course in group discussions, regardless of whether the teacher is present (Moore, 1989). The nature of the activities in the class is collaborative learning, which involves the use of teams "with peers seeing themselves as a source of authority and knowledge." Without much direction or involvement from the instructor, teams self-manage and communicate their decisions to the instructor" (Williams, Durray, \& Reddy, 2006, p. 593). In this sense, student-student contact promotes a learner-centred (Moore \& Kearsley, 1996; Anderson, 2003) and constructivist learning approach and the development of critical thinking and problem-solving skills (Speece, 2012). Furthermore, Foerderer et al. (2021) emphasized the importance of peer support in group discussions and engagement with peers in student satisfaction during online learning.

Because of the rise of technology-based learning environments, students' interactions with teachers and classmates have changed (Yukselturk \& Yildirim, 2008). Recognizing the importance of technology interfaces in interaction in online education, Hillman, Willis, and Gunawardena (1994) proposed a new type of interaction: student-technology, which was linked to Moore's interaction model. Student-technology interaction refers to individual students interacting with technology to communicate with course content, the course instructor, and other students in the course (Hillman, Willis, \& Gunawardena, 1994). Furthermore, internet-based learning, as a novel technology for remote online learning, "facilitates interaction and encourages learners and instructors to use multi-learning technologies" (Ahn, 2012, p. 1). In this regard, the internet has created a plethora of opportunities for synchronous interactions between students and teachers via web-video conferencing tools such as Zoom, Google Meet, and/or Microsoft Teams (Fatani, 2020). Alternatively, in online learning contexts such as Edmodo, Moodle, and/or Blackboard, threaded conversations are frequently used to enable interactive group discussions and exchange ideas among students or between students and the teacher in asynchronous mode (Speece, 2012).

\section{Recent Studies on Student Satisfaction in Relation to Interaction during COVID-19}

A number of scholars have conducted recent studies on student satisfaction and its relationship to interaction in remote online learning in the COVID-19 era. Muzammil, Sutawijaya, and Harsasi (2020) studied 4,305 students at an open and distance learning institution in Indonesia and discovered that interactions between student and teacher, student and content, and student and student influenced learning outcomes positively. Basith, Rosmaiyadi, Triani, and Fitri (2020) conducted an online learning satisfaction survey with 357 college students at STKIP Singkawang, Indonesia, during COVID 19. Students were satisfied with their interactions when the lecturer provided constructive feedback; they had more opportunities to discuss with classmates and course instructors. Fatani (2020) surveyed 162 Saudi Arabian undergraduate medical students in Pediatrics to assess student satisfaction with videoconferencing teaching quality during the COVID-19 pandemic. According to the survey, 82 per cent of respondents were extremely satisfied with the teaching quality of webvideoconferencing-delivered case-based discussion courses. Furthermore, the survey discovered that technology remains an important platform for instructors' instructional activities. Suryani and Sugianingrat (2021) studied 257 students at two private universities in Bali, Indonesia, who were actively engaged in e-learning during COVID-19. They discovered a significant positive relationship between student e-learning attitude and e-learning quality on student e-learning satisfaction and student e-learning satisfaction on e-learning system success. Gopal, Singh, and Aggarwal (2021) investigated factors influencing student satisfaction and performance in online classrooms during 
the COVID-19 epidemic. The study included 544 students enrolled in business management courses at Indian institutions. According to the study, instructor quality, course design, quick feedback, and student expectations all positively impact student satisfaction.

\section{Purpose and Objective}

This study aimed to investigate student satisfaction in remote online learning environments during COVID-19 in Indonesia. More specifically, this study sought to:

1. examine the relationship between student satisfaction and learning interaction,

2. understand the effects of interaction on student satisfaction in online learning environments.

The study's main research question is defined by the research objectives: What is the relationship between student satisfaction and interaction in remote online settings during COVID-19 in Indonesia? How can this student satisfaction be explained?

\section{Methods}

\section{Research Design and Rationale}

Quantitative research was used as a methodology in determining the answers to the research questions. According to Fraenkel, Wallen, and Hyun (2012), quantitative research investigates cause and effect, uses standardized measurements, and analyzes numerical data. In this study, multiple linear regression analyses were used to investigate cause and effect relationships and model the linear relationship between the independent and dependent variables. In this study, the independent variables were student-content interaction, student-teacher interaction, student-student interaction, and student-technology interaction, and the dependent variable was general student satisfaction.

\section{Participants and Procedure}

Participants in this study are undergraduate Informatics majors enrolled in the English Conversation Class (ECC) course at Institut Sains dan Teknologi Terpadu Surabaya [Surabaya Institute of Integrated Science and Technology] in Surabaya, Indonesia. During the second semester of 2019/2020, a questionnaire was distributed to the class and posted on Edmodo, reminding students who did not participate in the survey to do so. The survey was anonymous and was open for three weeks, from May 15 to June 5, 2020. The online survey was completed by 65 students, yielding a 100\% response rate. However, because of the small sample size, there is no claim of generalizability that the study's findings will be replicated in every remote online learning classroom.

\section{Instrumentation}

This study utilized Strachota's (2006) Student Satisfaction Survey, which explored learning interaction and satisfaction in online learning courses, to address the objectives of this study. The survey instrument contains five sections: learner-content, learner-instructor, learner-learner (Moore \& Kearsley, 1996), learner-technology (Hillman, Willis, \& Gunawardena, 1994), and general satisfaction (Strachota, 2003, 2006). "Items specific to learner-technology interaction were taken from the Cassidy and Eachus (2000) survey instrument, which had previously been pilot tested and demonstrated a Cronbach's alpha of .97 for the single construct of computer self-efficacy, which was equated as being synonymous with learner-technology interaction" (Strachota, 2006, p. 2). Strachota (2006) tested the survey instrument's reliability and validity with the help of field experts and a pilot test. Factor loading for learner-content interaction ranged from .604 to .780, factor loading for learnerinstructor interaction ranged from .594 to .841 , and factor loading for learner-learner interaction 
ranged from .588 to .786 . Cronbach's alpha for learner-content interaction and general satisfaction was .90, while it was .89 for learner-instructor interaction and learner-learner interaction (Strachota, 2006). As a result, the findings indicate that the Student Satisfaction Survey instrument is "a valid and highly reliable instrument that can be used at any institution of higher learning that offers online courses and is concerned with measuring the outcome of student satisfaction" (Strachota, 2006, p. 2). These were the underlying motivations for using the Student Satisfaction Survey instrument to investigate student satisfaction in remote online learning settings during COVID-19 in Indonesia.

The current research survey instrument contained 25 items (five for each interaction and five for satisfaction), with responses on a 4-point Likert scale ranging from 1 (strongly disagree), 2 (disagree), 3 (agree), and 4 (strongly agree) (strongly agree). After that, the survey instrument was tested on 12 students who were enrolled in an online Academic English course at the time. Based on the students' learning experiences with remote online education in Indonesian contexts, some of the items were slightly modified (wording changes) for the study. Demographic data were also collected regarding age, gender, home city, the primary device used for remote learning, familiarity with the internet technology, and online learning experience. The descriptive analysis of participants is presented in Table 1 in the Findings section.

\section{Data Analysis}

The research data were analyzed using the Statistical Package for the Social Sciences (SPSS) version 26. The survey tool employs a Likert-style rating scale to quantify each type of interaction and student satisfaction in the remote online environment, with 1 as strongly disagree and 4 as strongly agree. According to Jamieson (2005), the ordinal level of Likert scale survey response can be "described using frequencies/percentages of response in each category" (p. 1217). This is because "the mean (and standard deviation) are inappropriate for ordinal data" (Jamieson, 2005, p. 1217).

Descriptive statistics were used to examine the level of interaction and general satisfaction in remote online courses. The descriptive analysis of this study was presented in Tables 2-6 using the frequency/percentage of responses in each survey category. Spearman's Rho correlation analysis was used to determine the strength and direction of the relationship between the independent and dependent variables to analyse the first objective. Multiple regression analysis was used to address the second objective. It was a tool to examine the relation of multiple independent variables to the dependent variable. After that, a predictive research model is proposed.

\section{Findings}

\section{Descriptive Statistics of Participants of the Study}

The sample of this study includes 65 students majoring in informatics with an average age of 18.66 years $(S D=0.691$, range $=18-21)$. According to Table 1 , the gender distribution of the respondents is unequal, with more males (83.1 per cent) than females (16.9 per cent). Furthermore, 61.5 per cent of respondents studied in their hometown (East Java) of Surabaya, while 7.7 per cent studied from their homes on other Indonesian islands, namely Sulawesi and Bali. In the study, 61.5 per cent of students said they primarily used laptops for online learning, 27.7 per cent said they used personal computers, and 10.8 per cent said they used smartphones. Wi-Fi and data packets were used by 40 (61.5\%) and 25 (38.5\%) of respondents, respectively, to connect to the internet for distance learning courses. The students' familiarity with technology is satisfactory (97 per cent). In terms of online learning, 80 per cent of respondents said they had a good experience, while only 4.6 per cent said they had a poor experience. 
Table 1. Descriptive Statistics of Participants of the Study ( $=65)$

\begin{tabular}{|c|c|}
\hline & Responses (\%) \\
\hline Age (Mean, \pm SD) & $18.66, \pm 0.691$ \\
\hline \multicolumn{2}{|l|}{ Gender: } \\
\hline Female & $11(16.9)$ \\
\hline Male & $54(83.1)$ \\
\hline \multicolumn{2}{|c|}{ Studying from home-city: } \\
\hline Surabaya in Java & $40(61.5)$ \\
\hline Other cities in Java & $20(30.8)$ \\
\hline Outside Java & $5(7.7)$ \\
\hline \multicolumn{2}{|c|}{ Primary device used for remote learning: } \\
\hline Smartphone & $7(10.8)$ \\
\hline Laptop & $40(61.5)$ \\
\hline Personal computer & $18(27.7)$ \\
\hline \multicolumn{2}{|c|}{ Familiarity with technology: $*$} \\
\hline Good & 63 (96.9) \\
\hline Fair & $2(3.1)$ \\
\hline Poor & - \\
\hline \multicolumn{2}{|l|}{ Internet network: } \\
\hline $\mathrm{Wi}-\mathrm{Fi}$ & $40(61.5)$ \\
\hline Data package & $25(38.5)$ \\
\hline \multicolumn{2}{|c|}{ Experience of online learning: * } \\
\hline Good & $52(80)$ \\
\hline Fair & $10(15.4)$ \\
\hline Poor & $3(4.6)$ \\
\hline
\end{tabular}

Note: *Students' self-rated digital knowledge, responses using 3-point Likert scale, where 1 indicates Good; 2 for Fair; 3 for Poor

\section{Descriptive Statistics of Responses for Survey}

\section{Student-Content Interaction}

Table 2 displays the results of items in which 65 participants were asked to estimate their interaction with course content. More than $70 \%$ of participants agreed that the speaking tasks and projects in the course promoted their learning (Q3), the learning activities in the course required critical thinking skills that are conducive to their learning (Q4). In addition, the course materials used in class promoted their learning (Q1). According to the table, 26.2 per cent of participants strongly 
agree with Q2, indicating that the learning or website content provided in Edmodo for the course aided their learning, while 6.2 per cent strongly disagree. As shown in Table 2, participants generally positively perceive their interactions with course content during the online learning process.

Table 2. Descriptive Statistics of Responses for Student-Content Interaction Items

\begin{tabular}{|l|c|c|c|c|c|c|c|c|}
\cline { 2 - 9 } \multicolumn{1}{l|}{} & \multicolumn{7}{c|}{$\begin{array}{c}\text { Responses (N=65) } \\
\text { (frequency, percent) }\end{array}$} \\
\hline Student-Content Interaction & $\begin{array}{l}\text { Strongly } \\
\text { disagree }\end{array}$ & \multicolumn{2}{c|}{ Disagree } & \multicolumn{2}{c|}{ Agree } & \multicolumn{2}{c|}{ Strongly agree } \\
\cline { 2 - 10 } & f & $\%$ & f & $\%$ & f & $\%$ & f & $\%$ \\
\hline $\begin{array}{l}\text { Q1 } \\
\text { The course materials (games, songs, } \\
\text { films, vlog-making, prepared speech, } \\
\text { storytelling) used in this class have } \\
\text { facilitated my learning }\end{array}$ & 2 & 3.1 & 2 & 3.1 & 46 & 70.8 & 15 & 23.1 \\
\hline $\begin{array}{l}\text { Q2 } \\
\text { The learning/website content } \\
\text { provided in Edmodo for this course } \\
\text { has facilitated my learning }\end{array}$ & 4 & 6.2 & 5 & 7.7 & 39 & 60.0 & 17 & 26.2 \\
\hline $\begin{array}{l}\text { Q3 } \\
\text { The speaking tasks and projects in this } \\
\text { course have facilitated my learning }\end{array}$ & 2 & 3.1 & 4 & 6.2 & 49 & 75.4 & 10 & 15.4 \\
\hline $\begin{array}{l}\text { Q4 } \\
\text { The learning activities in this course } \\
\text { have required critical thinking skills } \\
\text { which facilitated my learning }\end{array}$ & 3 & 4.6 & 3 & 4.6 & 48 & 73.8 & 11 & 16.9 \\
\hline $\begin{array}{l}\text { Q5 } \\
\text { The learning activities in this course } \\
\text { have required problem solving skills } \\
\text { which facilitated my learning }\end{array}$ & 2 & 3.1 & 5 & 7.7 & 44 & 67.7 & 14 & 21.5 \\
\hline
\end{tabular}

\section{Student-Teacher Interaction}

Table 3 displays the results of items in which participants were asked to estimate their interaction with the teacher. The findings revealed that most participants agreed that their interactions with the teacher during the online learning process were positive. They agreed that the teacher was an active member of the discussion group and provided guidance for classroom discussions (Q6, 73.8\%), that the teacher provided individualized attention when needed ( $Q 8,72.3 \%)$, that the teacher was easily reached to communicate via public or private messages in the Zoom chat room $(09,72.3 \%)$, and that the teacher-facilitated their learning (Q10, 72.3\%). According to Table 3, 27.7 per cent of participants strongly agreed with Q7, stating that they had received immediate/direct feedback from the teacher. As shown in Table 3, participants generally positively perceive their interactions with their teacher during the online learning process. 
Table 3. Descriptive Statistics of Responses for Student-Teacher Interaction Items

\begin{tabular}{|l|c|c|c|c|c|c|c|c|}
\cline { 2 - 9 } \multicolumn{1}{l|}{} & \multicolumn{7}{c|}{$\begin{array}{c}\text { Responses (N=65) } \\
\text { (frequency, percent) }\end{array}$} \\
\hline \multirow{2}{*}{ Student-Teacher Interaction } & $\begin{array}{l}\text { Strongly } \\
\text { disagree }\end{array}$ & \multicolumn{2}{c|}{ Disagree } & \multicolumn{2}{c|}{ Agree } & \multicolumn{2}{c|}{ Strongly agree } \\
\cline { 2 - 10 } & f & $\%$ & f & $\%$ & f & $\%$ & f & $\%$ \\
\hline $\begin{array}{l}\text { Q6 } \\
\text { In this course the teacher has been } \\
\text { an active member of the discussion } \\
\text { group offering direction to class } \\
\text { discussion }\end{array}$ & 1 & 1.5 & 2 & 3.1 & 48 & 73.8 & 14 & 21.5 \\
\hline $\begin{array}{l}\text { Q7 } \\
\text { I have received immediate/direct } \\
\text { feedback from my teacher }\end{array}$ & 2 & 3.1 & 5 & 7.7 & 40 & 61.5 & 18 & 27.7 \\
\hline $\begin{array}{l}\text { Q8 } \\
\text { I have been able to get individualized } \\
\text { attention in zoom from my teacher } \\
\text { when needed }\end{array}$ & 3 & 4.6 & 5 & 7.7 & 47 & 72.3 & 10 & 15.4 \\
\hline $\begin{array}{l}\text { Q9 } \\
\text { I have been able to communicate } \\
\text { easily via public or private messages } \\
\text { with the teacher in Zoom chat room. }\end{array}$ & 1 & 1.5 & 5 & 7.7 & 47 & 72.3 & 12 & 18.5 \\
\hline $\begin{array}{l}\text { Q10 } \\
\text { In this course the teacher has } \\
\text { functioned as the facilitator } \\
\text { by continuously encouraging } \\
\text { communication }\end{array}$ & 2 & 3.1 & 6 & 9.2 & 47 & 72.3 & 10 & 15.4 \\
\hline
\end{tabular}

\section{Student-Student Interaction}

Table 4 illustrates the results of items in which participants were asked to estimate their interactions with classmates. According to the findings, more than 70\% of participants agreed with Q12 and Q15. Participants believe that Zoom's chat room allows them to share critical thinking with other students and that the online course encourages them to discuss ideas and concepts with their classmates. According to the table, 18.5 per cent of participants strongly agree that Zoom's breakout room allows them to solve problems with other students (Q11). As shown in Table 4, participants have a positive perception of their interactions with their classmates during the online learning process.

\section{Student-Technology Interaction}

Table 5 displays the outcomes of items in which participants were asked to estimate their interaction with the technology used in the online course. According to the results, more than $70 \%$ of participants agreed with Q16, Q18, and Q20. Participants believe that they enjoy working with computers, are confident in their ability to use computers, and are a useful tool for learning. For example, 24.6 per cent of participants strongly agreed with "Q17: computers make me more productive," while 20 per cent strongly agreed with "Q16: I like to work with computers." Furthermore, as shown in the table, 7.7 per cent of participants disagreed with "Q18: I am very confident in my ability to use computers, Q19: using computers make learning more interesting, and Q20: computers are good aid for learning." Table 5 shows that participants have a positive experience with the technology used for online learning. 
Table 4. Descriptive Statistics of Responses for Student-Student Interaction Items

\begin{tabular}{|c|c|c|c|c|c|c|c|c|}
\hline \multirow{3}{*}{ Student-Student Interaction } & \multicolumn{8}{|c|}{$\begin{array}{c}\text { Responses ( } \mathrm{N}=65 \text { ) } \\
\text { (frequency, percent) }\end{array}$} \\
\hline & \multicolumn{2}{|c|}{$\begin{array}{l}\text { Strongly } \\
\text { disagree }\end{array}$} & \multicolumn{2}{|c|}{ Disagree } & \multicolumn{2}{|c|}{ Agree } & \multicolumn{2}{|c|}{ Strongly agree } \\
\hline & $f$ & $\%$ & $f$ & $\%$ & $f$ & $\%$ & $f$ & $\%$ \\
\hline $\begin{array}{l}\text { Q11 } \\
\text { In this course the breakout rooms in } \\
\text { Zoom have provided opportunity for } \\
\text { problem solving with other students }\end{array}$ & 3 & 4.6 & 5 & 7.7 & 45 & 69.2 & 12 & 18.5 \\
\hline $\begin{array}{l}\text { Q12 } \\
\text { In this course the chat rooms in Zoom } \\
\text { have provided opportunity for sharing } \\
\text { critical thinking with other students }\end{array}$ & 5 & 7.7 & 6 & 9.2 & 49 & 75.4 & 5 & 7.7 \\
\hline $\begin{array}{l}\text { Q13 } \\
\text { In this course the use of Edmodo } \\
\text { and Zoom has created a sense of } \\
\text { community among students }\end{array}$ & 6 & 9.2 & 6 & 9.2 & 44 & 67.7 & 9 & 13.8 \\
\hline $\begin{array}{l}\text { Q14 } \\
\text { I have received direct feedback from } \\
\text { students in Zoom }\end{array}$ & 6 & 9.2 & 6 & 9.2 & 45 & 69.2 & 8 & 12.3 \\
\hline $\begin{array}{l}\text { Q15 } \\
\text { This online course has encouraged me } \\
\text { to discuss ideas and concepts with } \\
\text { other students }\end{array}$ & 4 & 6.2 & 4 & 6.2 & 47 & 72.3 & 10 & 15.4 \\
\hline
\end{tabular}

Table 5. Descriptive Statistics of Responses for Student-Technology Interaction Items

\begin{tabular}{|l|c|c|c|c|c|c|c|c|}
\cline { 2 - 10 } \multicolumn{1}{c|}{} & \multicolumn{7}{c|}{$\begin{array}{c}\text { Responses (N=65) } \\
\text { (frequency, percent) }\end{array}$} \\
\hline \multirow{2}{*}{ Student-Technology Interaction } & $\begin{array}{l}\text { Strongly } \\
\text { disagree }\end{array}$ & \multicolumn{2}{c|}{ Disagree } & \multicolumn{2}{c|}{ Agree } & \multicolumn{2}{c|}{ Strongly agree } \\
\cline { 2 - 10 } & $\mathrm{f}$ & $\%$ & $\mathrm{f}$ & $\%$ & $\mathrm{f}$ & $\%$ & $\mathrm{f}$ & $\%$ \\
\hline $\begin{array}{l}\text { Q16 } \\
\text { I enjoy working with computers* }\end{array}$ & 2 & 3.1 & 2 & 3.1 & 48 & 73.8 & 13 & 20.0 \\
\hline $\begin{array}{l}\text { Q17 } \\
\text { Computers make me much more } \\
\text { productive }\end{array}$ & 2 & 3.1 & 2 & 3.1 & 45 & 69.2 & 16 & 24.6 \\
\hline $\begin{array}{l}\text { Q18 } \\
\text { I am very confident in my abilities to } \\
\text { use computers }\end{array}$ & 3 & 4.6 & 5 & 7.7 & 47 & 72.3 & 10 & 15.4 \\
\hline $\begin{array}{l}\text { Q19 } \\
\text { Using computers makes learning more } \\
\text { interesting }\end{array}$ & 3 & 4.6 & 5 & 7.7 & 45 & 69.2 & 12 & 18.5 \\
\hline $\begin{array}{l}\text { Q20 } \\
\text { Computers are good aid to learning }\end{array}$ & 2 & 3.1 & 5 & 7.7 & 46 & 70.8 & 12 & 18.5 \\
\hline
\end{tabular}

Note: * the term 'computers' refers to laptops, personal computers, or smartphones. 


\section{General Satisfaction}

Table 6 displays the outcomes of items in which participants were asked to estimate their overall satisfaction with online courses. According to the findings, 73.8 per cent of participants said the online course experience helped them improve their speaking communication skills (Q25), and the online course met their learning objectives (Q22). According to the table, 24.6 per cent of participants strongly agree that online courses are as effective as in-person courses (Q24), while 6.2 per cent strongly disagree. According to Table 6, 66.2 per cent of participants were satisfied with the online course, while 15.4 per cent were dissatisfied (Q21). Thus, table 6 shows that participants are generally satisfied with online learning.

Table 6. Descriptive Statistics of Responses for General Satisfaction Items

\begin{tabular}{|c|c|c|c|c|c|c|c|c|}
\hline \multirow{3}{*}{ General Satisfaction } & \multicolumn{8}{|c|}{$\begin{array}{c}\text { Responses ( } \mathrm{N}=65) \\
\text { (frequency, percent) }\end{array}$} \\
\hline & \multicolumn{2}{|c|}{$\begin{array}{l}\text { Strongly } \\
\text { disagree }\end{array}$} & \multicolumn{2}{|c|}{ Disagree } & \multicolumn{2}{|c|}{ Agree } & \multicolumn{2}{|c|}{ Strongly agree } \\
\hline & f & $\%$ & f & $\%$ & f & $\%$ & $f$ & $\%$ \\
\hline $\begin{array}{l}\text { Q21 } \\
\text { I am very satisfied with this online } \\
\text { course }\end{array}$ & 2 & 3.1 & 10 & 15.4 & 43 & 66.2 & 10 & 15.4 \\
\hline $\begin{array}{l}\text { Q22 } \\
\text { This online course meets my learning } \\
\text { needs }\end{array}$ & 1 & 1.5 & 5 & 7.7 & 48 & 73.8 & 11 & 16.9 \\
\hline $\begin{array}{l}\text { Q23 } \\
\text { I have learned as much in this online } \\
\text { course as compared to a face-to-face } \\
\text { course }\end{array}$ & 5 & 7.7 & 5 & 7.7 & 45 & 69.2 & 10 & 15.4 \\
\hline $\begin{array}{l}\text { Q24 } \\
\text { I feel this online course is as effective } \\
\text { as face-to-face course }\end{array}$ & 4 & 6.2 & 5 & 7.7 & 40 & 61.5 & 16 & 24.6 \\
\hline $\begin{array}{l}\text { Q25 } \\
\text { I feel this online course experience } \\
\text { has helped improve my spoken } \\
\text { communication skills }\end{array}$ & 2 & 3.1 & 2 & 3.1 & 48 & 73.8 & 13 & 20.0 \\
\hline
\end{tabular}

\section{Validity and Reliability of the Study Instrument}

We used factor analysis to see if we could find the theoretically assumed student satisfaction and interaction in our data. The five satisfaction-related items had factor loadings ranging from .713 to .917 and a Cronbach's alpha of .889. Factor loading for student-content interaction ranged from .798 to .954 , factor loading for student-teacher interaction ranged from .707 to .949 , factor loading for student-student interaction ranged from .899 to .941 , and factor loading for student-technology interaction ranged from .755 to .879 . The internal consistency of student-content was $\alpha=.933$, the internal consistency of student-teacher was $\alpha=.931$, the internal consistency of student-student was $\alpha=.954$, and the internal consistency of student-technology was $\alpha=.857$. With reliability coefficients greater than .07, all constructs were deemed reliable (Babbie, 2013).

\section{Relationship between Satisfaction and Interaction}

The first goal of the study was to investigate the relationship between student satisfaction and interaction. According to Spearman's rho correlation analysis, there was a statistically significant 
positive relationship between satisfaction and interaction $\left(r_{s}(63)=.824, \rho<.001\right)$. The scatterplot for general satisfaction and interaction is shown in Figure 1 . This finding implies that interaction is significantly correlated with student satisfaction.

Figure 1. Positive Relation between Interaction and Student Satisfaction

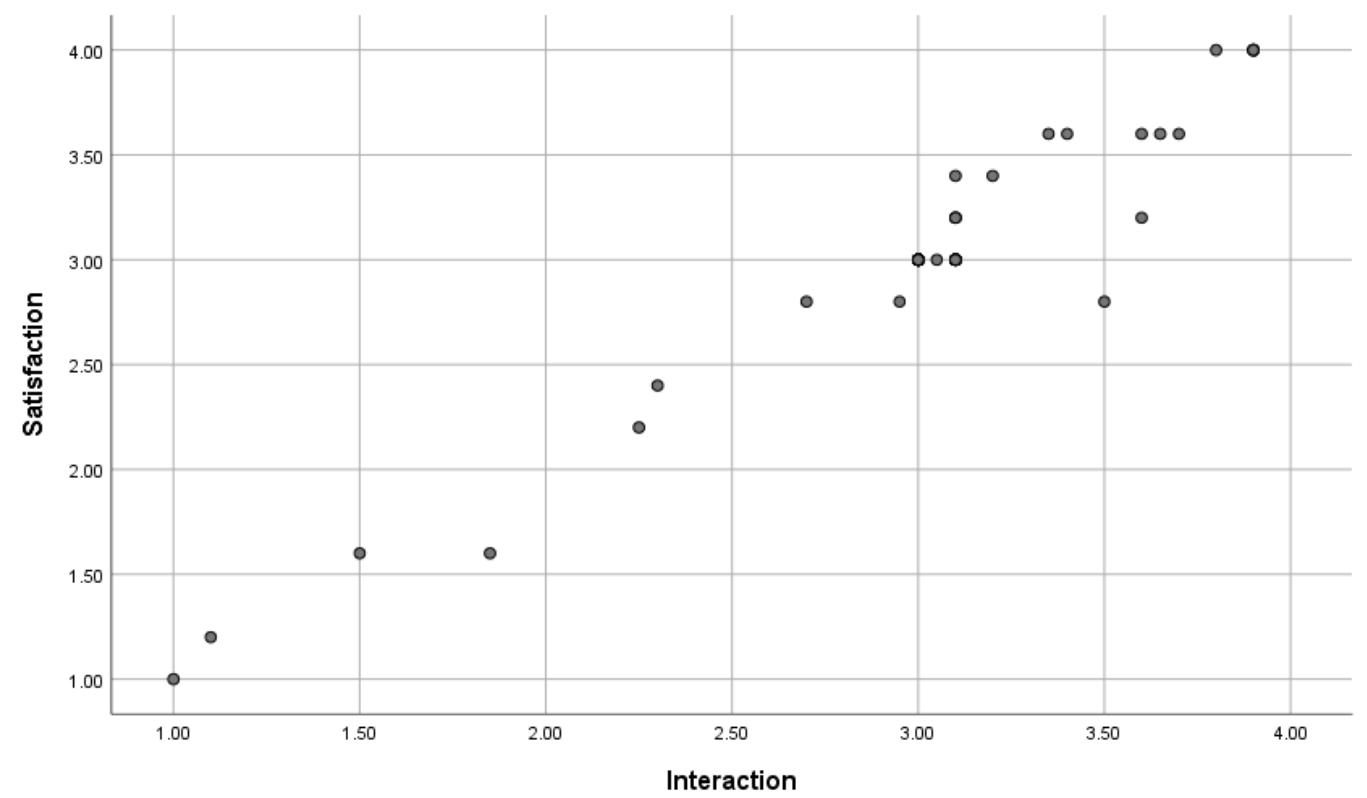

Note: $r_{s}(63)=.824, \rho<.001$

The relationship between satisfaction and each type of interaction is shown in Table 7. The strongest correlations to satisfaction are student-teacher $\left(r_{s}=.854\right)$ and student-student $\left(r_{s}=.818\right)$. While student content has a moderate correlation with satisfaction $\left(r_{s}=.795\right)$, student technology has the lowest correlation $\left(r_{s}=.635\right)$.

Table 7. Relationship of Satisfaction and Each Type of Interaction

\begin{tabular}{|c|c|c|c|c|c|c|}
\hline & & & $\begin{array}{l}\text { Student- } \\
\text { Content }\end{array}$ & $\begin{array}{l}\text { Student- } \\
\text { Teacher }\end{array}$ & $\begin{array}{l}\text { Student- } \\
\text { Student }\end{array}$ & $\begin{array}{l}\text { Student- } \\
\text { Technology }\end{array}$ \\
\hline \multirow[t]{3}{*}{$\begin{array}{l}\text { Spearman's } \\
\text { rho }\end{array}$} & Satisfaction & $\begin{array}{l}\text { Correlation } \\
\text { Coefficient }\end{array}$ & $.795^{* *}$ & $.854^{* *}$ & $.818^{* *}$ & $.635^{* *}$ \\
\hline & & Sig. (2-tailed) & .000 & .000 & .000 & .000 \\
\hline & & $\mathrm{N}$ & 65 & 65 & 65 & 65 \\
\hline
\end{tabular}

Note: ${ }^{* *}$. Correlation is significant at the 0.01 level (2-tailed).

\section{Effects of Each Type of Interaction on Student Satisfaction}

The study's second objective was to understand the effects of interaction on student satisfaction in remote online learning courses. Multiple regression was used to assess the effect of each type of interaction on student satisfaction. Table 8 displays the results of the study's multiple linear regression. The most powerful predictor of student satisfaction was student-content interaction (Adjusted $R^{2}=0.937, \rho<0.001$ ), followed by student-student interaction (Adjusted $R^{2}=0.896$, $\rho<0.001$ ), student-teacher interaction (Adjusted $R^{2}=0.851, \rho<0.001$ ), and student-technology 
interaction (Adjusted $R^{2}=0.841, \rho<0.001$ ). In conclusion, student satisfaction is primarily influenced by student-content interaction.

Table 8. Effects of Each Type of Interaction on Satisfaction

\begin{tabular}{|c|c|c|c|c|}
\hline \multicolumn{5}{|c|}{ Satisfaction } \\
\hline & Adjusted $R^{2}$ & $\beta$ & $t$ & Sig \\
\hline Student-Content Interaction & $.937(\mathrm{~F}=191.870)$ & & & $.000 * * *$ \\
\hline Q1: The course materials have facilitated my learning & & .124 & 2.354 & $.022 *$ \\
\hline $\begin{array}{l}\text { Q2: The learning/website content provided in } \\
\text { Edmodo has facilitated my learning }\end{array}$ & & .558 & 10.856 & $.000 * * *$ \\
\hline $\begin{array}{l}\text { Q4: The learning activities required critical thinking } \\
\text { skills which facilitated my learning }\end{array}$ & & .285 & 2.284 & $.026 *$ \\
\hline $\begin{array}{l}\text { Q5: The learning activities required problem solving } \\
\text { skills which facilitated my learning }\end{array}$ & & .160 & 2.273 & $.027^{*}$ \\
\hline Student-Teacher Interaction & $\begin{array}{l}.851 \\
(F=74.114)\end{array}$ & & & $.000 * * *$ \\
\hline $\begin{array}{l}\text { Q7: I have received immediate/direct feedback from } \\
\text { my teacher }\end{array}$ & & .402 & 4.445 & $.000 * * *$ \\
\hline $\begin{array}{l}\text { Q8: I have been able to get individualized attention in } \\
\text { zoom from my teacher when needed }\end{array}$ & & .644 & 2.445 & $.017^{*}$ \\
\hline Student-Student Interaction & $\begin{array}{l}.896 \\
(F=110.748)\end{array}$ & & & $.000 * *$ \\
\hline $\begin{array}{l}\text { Q11: The breakout rooms in Zoom have provided } \\
\text { opportunity for problem solving with other students }\end{array}$ & & .394 & 2.733 & $.008 * *$ \\
\hline $\begin{array}{l}\text { Q12: The chat rooms in Zoom have provided } \\
\text { opportunity for sharing critical thinking with other } \\
\text { students }\end{array}$ & & .197 & 2.086 & $.041^{*}$ \\
\hline Student-Technology Interaction & $\begin{array}{l}.841 \\
(F=68.681)\end{array}$ & & & $.000 * * *$ \\
\hline Q17: Computers make me much more productive & & .498 & 3.316 & $.002 * *$ \\
\hline $\begin{array}{l}\text { Q18: I am very confident in my abilities to use } \\
\text { computers }\end{array}$ & & .652 & 7.163 & $.000 * * *$ \\
\hline
\end{tabular}

Note: *. Significant at the $0.05,{ }^{* *}$. Significant at the 0.01 level, ***. Significant at the 0.001 level, $\beta=$ standardized regression coefficient, $R^{2}=$ adjusted coefficient of determination, $N=65$.

Table 8 also shows ten items of interaction influencing student satisfaction in remote online learning. The following items have the highest weight coefficients (>0.4): "Q18 I am very confident in my abilities to use computers" (0.652), "Q8 I have been able to get individualized attention in zoom from my teacher when needed" (0.644), "Q2 The learning/website content provided in Edmodo has facilitated my learning" (0.558), "Q17: Computers make me much more productive" (0.498), and "Q7 I am very confident in my abilities to use computers" (0.402).

\section{Discussion}

The framing concept for this study is investigating student satisfaction in remote online learning during COVID-19 in Indonesia. The findings of this study reveal that each type of interaction has 
an impact on student satisfaction. Thus, Moore's (1989) model of interaction which included the student-technology interaction provided by Hillman et al. (1994), is entirely supported by this study. Furthermore, these findings are consistent with other research that employs the interaction typology and discovers a strong relationship between student-content interaction and satisfaction (Yekselturk \& Yildirim, 2008; Sher, 2009; Ahn, 2012; Kuo, Walker, Belland, \& Schroder, 2014). In addition, the study emphasizes the relevance of technological supports, instructional supports, peer-supports, and course content designed to facilitate and promote online learning. The discussion that follows goes into greater detail about the findings.

\section{Interaction}

\section{Student-Content Interaction}

According to the regression results, student-content interaction is the most influential predictor of satisfaction (93.70 per cent). Importantly, four of the five built-in items were significant in predicting student satisfaction, with the item "Q2 The learning/website content provided in Edmodo has facilitated my learning" being the strongest predictor within this construct. This finding suggests that the course content provided in Edmodo improved students' understanding and autonomy in their learning (Ngo \& Ngadiman, 2019). In support of our finding, Kumar, Saxena, and Baber (2021) surveyed 435 undergraduate and graduate management students and discovered that "both the learning content and website content provided under the online study environment are important factors of e-learning quality, having a positive effect on e-learning quality and student satisfaction" (p. 11). Gopal, Singh, and Anggarwal (2021) discovered that the design of the course content is an important factor influencing student satisfaction in a survey of 544 M.B.A students in India. According to the study, "the design should be in an effective manner so that students can easily understand the content without any problems" (p. 15). Furthermore, Edmodo is easy to use and navigate at any time and from any location. The ease with which students can obtain online lesson materials may influence how well they interact with course content (Anderson, 2003). This situation is most likely the source of student satisfaction.

The other built-in items that significantly predicted student satisfaction were "Q4: the learning activities required critical thinking skills, which facilitated my learning," "Q1: the course materials (games, songs, films, vlog-making, prepared speech, storytelling) used in this class facilitated my learning," and "Q5: the learning activities in this course required problem-solving thinking skills, which facilitated my learning." These findings imply that incorporating interactive learning materials into the classroom can help students improve their comprehension, elaborate and reflect on their ideas, and increase their motivation (Moore, 1989; Kuo, Walker, Belland, \& Schroder, 2014). In remote learning settings, interactive learning activities help students become more involved in the topic (Higgins et al., 2002 cited in Ahn, 2012). A well-designed and high-quality content structure enable students to study and create information on their own, resulting in improved student performance and satisfaction (Moore \& Kearsley, 1996; Ahn, 2012).

\section{Student-Student Interaction}

The second most important predictor of student satisfaction was student-student interaction (89.6 per cent). Only two of the five built-in items for this interaction were significant predictors of satisfaction (see Table 8), namely "Q11: in this course, the Zoom breakout rooms have provided opportunity for problem-solving with other students," and "Q12: in this course, the Zoom chat rooms have provided opportunity for sharing critical thinking with other students." Students reflected on the relatively high collaborative tasks in online learning mediated by Zoom breakout rooms and chat rooms. Students can use Zoom breakout rooms to supplement their class with quality peer/ group conversations. Furthermore, students who received pertinent, constructive peer criticism 
and benefited from social interaction were more satisfied with their online learning experience. Our findings support Jung, Choi, Lim, and Leem's (2002) hypothesis that collaborative activities engaged students in the learning process, implying that student-student interaction significantly impacted student satisfaction. Ivankova and Stick (2007) presented the interview results, claiming that the online format enabled students to learn from other students' work, resulting in the formation of a virtual community among the students. Peer support in group discussions and opportunities to communicate with peers are two critical aspects that affect student satisfaction, according to the current study by Foerderer, Hoffman, Schneider, and Prichard (2021). Despite their plausibility, the findings of this study contradict those of Ahn (2012) and Alqurashi (2019), who discovered that student-student interaction has no effect on satisfaction.

\section{Student-Teacher Interaction}

The third most important predictor of satisfaction was student-teacher interaction (85.1 per cent). "Q8: I have been able to get individualized attention in zoom from my teacher when needed" and "Q7: I have received immediate/direct feedback from my teacher" were found to be highly and significantly predictive of student satisfaction (see Table 8). These findings highlight the significance of instructor presence and support in online learning and direct feedback on tasks through online class discussion. One possible explanation is that students in this study experienced fully online learning remotely for the first time using both synchronous and asynchronous approaches. Hence, the teacher's presence and active feedback in-class discussion became important aspects of improving their learning. "Conceptually, the more the instructor is present, the more engaged a student becomes, and the more satisfied he becomes" (Garrison et al., 2000; Jaggars et al., 2013; Gray \& DiLoreto, 2016, p. 14). Furthermore, Shea, Li, and Pickett (2006) stated that the instructor's most important role in an online learning environment is establishing his presence and personality in the course content, discussions, and activities. "Through active intervention, the teacher draws in less active participants, acknowledges individual contributions, reinforces appropriate contributions, focuses discussion, and generally facilitates an educational transaction" (Garrison et al., 2000, p.101). The findings of our study are consistent with the findings of previous studies. According to Suryani and Sugianingrat (2021), the most important factor influencing student satisfaction is the instructor's quality (e.g., efficiency, passion throughout the online session). Furthermore, Foerderer et al. (2021) discovered that teachers' assistance and guidance and their time availability contributed to student satisfaction. Our findings are also consistent with Gray and DiLoreto's previous study (2016). According to the findings, establishing instructor presence in online courses can be accomplished by facilitating the course to promote positive interaction between the instructor and students, resulting in student satisfaction (Gray \& DiLoreto, 2016). Teacher feedback, according to our findings, had an effect on student satisfaction. The findings of this study were consistent with the findings of previous studies. Gopal, Singh, and Anggarwal (2021) discovered that prompt feedback from an instructor had an effect on student satisfaction. Ngo and Ngadiman (2019) discovered that providing students with immediate teacher feedback allows them to assess their understanding of course content and improve their performance.

Our findings also show that using web-video conferencing apps improves interpersonal interactions between teachers and students and students, providing a similarity to (conventional) classroom activities. This finding is consistent with the previous study, indicating that students were satisfied with the teacher's presence, and web-video conferencing aids in developing a social presence for both the teacher and the students and engaging students in virtual classrooms (Fatani, 2020). Furthermore, Jung, Choi, Lee, and Leem (2002) discovered that "collaboration among learners is related more to learner satisfaction than to learning outcome in WBI" (Web-Based Instruction) (p. 159). 


\section{Student-Technology Interaction}

The fourth most important indicator of satisfaction was student-technology interaction (84.1 per cent). Looking at the built-in items for this construct, two of them, "Q17: computers make me much more productive," and "Q18: I am very confident in my ability to use computers," contributed significantly to student satisfaction. This finding appears to be acceptable in our study because 1) the participants are Informatics students, 2) the majority of students (61.5 per cent) were working with a laptop for their online learning, 3 ) the vast majority of students (96.9 per cent) were proficient in internet technology, and 4 ) the majority of students ( 80 per cent) had a positive experience with computers.

S. Iglesias-Pradas et al. (2021) surveyed 43 students from the Telecommunication Engineering department in Madrid. They discovered that students with the highest level of digital competence are more likely and proficient to use digital tools. In addition, students with digital devices and previous learning experiences tend to interact more with digital tools or ICT to take notes and complete assignments. Furthermore, Du (2004) conducted a survey of 237 undergraduate library and information science students from a mid-southwestern state university in the United States from 2001 to 2003 and discovered a "statistically significant correlation between computer competency and students' enjoyment level" (p. 9). According to the study, "students believe web-based courses are easier if they have sufficient computer background" (p. 10). It is worth noting that students who have a "higher level of computer competency are likely to be more satisfied with distance learning" (Du, 2004, p. 10).

In terms of IT infrastructure, the majority of students in Surabaya, East Java, had access to an internet network with both Wi-Fi and data packages, and 61.5 per cent of them did their online learning from home. Surabaya ranked 10th in the Ookla Speed Test Global Index for 2020 (Cahya, 2021), with a speed of $19.91 \mathrm{Mbps}$. In our study, it is reasonable to believe that relatively wellsupported digital gadgets and the internet network (IT infrastructure) are critical tools in online learning environments and contribute to student satisfaction. Suryani and Sugianingrat (2021), who conducted a study on student e-learning satisfaction during the COVID-19 pandemic in Bali, Indonesia, confirm that internet quality is one of the major factors determining student satisfaction. Students were able to easily communicate with the course content, the facilitator, and other students due to their skill and competency in digital learning, as well as the reasonably fast internet bandwidth (Hillman et al., 1994; Ahn, 2012; Fatani, 2020, Kusnayat et al., 2020).

\section{Student General Satisfaction}

As shown in Table 6, the majority of participants had positive feelings about the English Conversation Class course offered in a remote online learning context. According to their self-reports, the students thought the online course helped them improve their spoken communication skills, was as successful as face-to-face courses and matched their goals. The findings may indicate that students enjoy and are satisfied with remote online learning. Basith et al. (2020) conducted an online learning satisfaction study in Singkawang, Indonesia, during the COVID-19 pandemic. They discovered that students are satisfied with the course's learning objectives, tailored to their needs and expectations. According to Gopal et al. (2021), meeting students' expectations in an online course is a critical component of satisfaction. It was discovered that students enrolled in online courses believed they had met the learning objective, which was one of the factors contributing to student satisfaction (Foerderer et al., 2021).

Our research found that combining synchronous (Zoom) and asynchronous (Edmodo) tools improves student satisfaction with online learning courses. This is consistent with the previous study's findings. Almusharraf and Khahro (2020) conducted a survey of 283 students at one higher 
education institution in Saudi Arabia. They discovered that students were extremely satisfied with using an integrated approach of synchronous (Google Hangouts) and asynchronous learning (Google Classroom and Moodle).

\section{Conclusions and Implications}

This study investigated students' satisfaction in remote online learning environments during COVID-19 in Indonesia. Our findings show that students in an online English Conversation Class course recognized a strong link between classroom interaction and learning satisfaction. In this study, it was clear that students positively perceived their interaction with course content, instructor, classmates, and technology in the online environment. However, the findings do point out factors that influence student satisfaction in remote online learning courses.

According to their self-reports, the majority of students are satisfied with the English Conversation Class course delivered via remote online learning. Students clearly stated that the online course helped them improve their spoken communication skills, was as effective as faceto-face courses, and matched their objectives. Students are also satisfied with the online course's learning resources. The combination of synchronous and asynchronous online learning platforms is regarded as the most effective to facilitate their learning.

These findings have some implications for the body of knowledge in the field of student satisfaction, where the emphasis must be placed on incorporating various types of interaction into Web-based learning processes during the COVID-19 pandemic. Course content that can help students learn during the pandemic is essential (Kumar et al., 2021; Gopal et al., 2021). The presence of a teacher during online learning has a significant impact on student satisfaction (Suryani \& Sugianingrat, 2021; Foerderer et al., 2021; Gray \& DiLoreto, 2016). In the context of Indonesia, where students have experienced fully online learning for the first time, the teacher's presence can motivate, direct, and establish student security that they can learn in the same way as traditional classes (Suryani \& Sugianingrat, 2021, Jaggars et al., 2013). These will aid in reducing their stress during the pandemic (Kusnayat et al., 2020). Student group discussions are among the most important predictors of student satisfaction during the pandemic (Foerderer et al., 2021). The use of synchronous learning tools has encouraged students in virtual classes to discuss ideas and concepts with other students. Furthermore, this research adds to the body of knowledge by emphasizing the importance of lowcost internet data packages and an integrated synchronous and asynchronous learning approach in the context of online learning in Indonesia.

This study's practical implications frame the teaching-learning process in remote online learning. This study demonstrates that the integrated synchronous and asynchronous online approaches facilitate lecture delivery and interaction with the teacher, classmates, and technology. Combining synchronous and asynchronous online approaches, seen as a new instructional paradigm in the Indonesian context, is a potential educational model emerging as a result of the COVID-19 pandemic and in response to the new higher education policy issued in the Ministry of Education and Culture Regulation No 3, 2020 concerning Independent Campus (Kampus Merdeka) (Dikti Kemendikbud, 2020). This new paradigm of teaching and learning will facilitate the implementation of the Independent Campus policy, which emphasizes a student-centered approach (independent learning) through media technology or ubiquitous learning.

To put the Independent Campus policy into action, faculty must experiment with combining traditional learning and e-learning and integrating synchronous and asynchronous online learning. It implies that Learning Management System platforms are required to assist teachers in managing their lectures and courses, monitor and evaluate students, assign grades, track course attendance, and perform other administrative tasks as mandated by educational institutions (Coman et al., 2020). Teachers can use these platforms to upload and provide students with information and learning resources, and students will be expected to log in daily, read the daily messages, and complete any tasks assigned to them by the teacher at any time and from any location (Dziuban 
et al., 2004; Jaggars et al., 2013). This type of learning promotes a student-centered approach by using an e-learning platform (Moore, 1989; Anderson, 2003), which is in line with the goal of the Independent campus policy.

To improve the quality of e-learning or online learning, universities, faculties and online content specialists should create and develop instructional content (in the future, digital curriculum) that teachers can use in their classrooms. It is critical to provide interactive course content or web content that increases students' learning motivation while also facilitating critical thinking and problem-solving skills (Moore \& Kearsley, 1996), as also suggested in this study. Furthermore, a good content design encourages real-time interaction between students or among students and between students and instructors (Moore, 1989; Ahn, 2012). The expectation is that students be given various times to engage synchronously, whether in whole group, small group, or individual settings. Furthermore, infusing audio, video, and web-content resources throughout lectures allows students to engage with content in various ways while also creating a strong instructor presence (Jaggars et al., 2013). In support of the Independent Campus policy, when ready, universities and faculties can open online courses or modules that students across Indonesia can access, in which they can spend three semesters studying outside their core study program at home-university, different universities in Indonesia, and potentially overseas, and outside universities (non-tertiary education), according to the Regulation of the Minister of Education and Culture Number 3 of 2020 Article 15 (2) (Dikti Kemendikbud, 2020).

The pandemic has benefited teachers who have become more technologically savvy. As a result, teachers have been compelled to improve their instructional design and delivery abilities through the use of technology. To comply with the Independent Campus policy, teachers, in collaboration with online content experts, must learn, create, and develop a web-course design to improve online learning processes for each course. In addition, teachers should adapt their teaching methods to include more visual and interpersonal communication through webinars or other interactive media (YouTube, podcasts) and more student interaction.

In light of blended education, some recommendations may be made. First and foremost, the government should improve and stabilize Indonesia's information technology infrastructure. Second, the government can provide loans to deserving students through universities to own a laptop or computer. Third, universities should offer online courses to students and provide online learning training to teachers.

\section{Limitations and Suggestions for Future Research}

Although this study identified and explained the relationship between interaction and satisfaction in remote online learning during the COVID-19, some significant limitations should be noted. First, the sampling was chosen for convenience, and the sample size was small. The results are specific to one institution, specifically one engineering department and one subject-a bachelor's degree in Informatics - as a case study. As a result, we acknowledge that these findings may not apply to other online learning environments. Second, we used Strachota's Student Satisfaction Survey instrument $(2003,2006)$. Although it is a valid and reliable instrument for researching student satisfaction with online learning courses, we should have investigated another instrument used to predict student satisfaction during the COVID-19 pandemic in Indonesia, which is more relevant to the study. For example, the 2020 home study questionnaire for elementary to high school students developed by the Ministry of Education and Culture can be used as a starting point for creating and developing a survey instrument by combining it with Strachota's Student Satisfaction Survey instrument.

More research will be needed to determine how well the findings of this study apply to participants from different majors, faculties, and/or universities. It will be more interesting to investigate student satisfaction in the Indonesian context when comparing traditional and online learning. A stronger emphasis on developing a survey instrument from the perspective of student learning in the Indonesian context could be interesting for future research. Another area for future 
research is the blended learning approach used in Indonesian higher education institutions, which combines traditional and online learning (via e-platforms) and synchronous and asynchronous learning. It would be very interesting to investigate the relationship between blended learning and current higher education policy: Independent Learning (Kampus Merdeka), focusing on studentcentered approaches and the use of ICT and the internet.

\section{Note:}

We appreciate the positive and constructive feedback from the reviewers on the manuscript. We would like to thank all of the students who took part in the survey, as well as their perseverance in continuing their education during the COVID-19.

\section{References}

Ahn, B. (2012). General Satisfaction of Students in 100\% Online Courses in the Department of Learning Technologies at the University of North Texas. Unpublished Doctoral Dissertation, University of North Texas. Available at https://digital.library.unt.edu/ark:/67531/metadc115042/m2/1/ high_res_d/dissertation.pdf [Accessed 18 May 2021].

Allen, I. \& Seaman, J. (2010). Online Education Grows by almost a Million Students. Eighth Annual Sloan Survey of Online Education Shows Economy Still Driving Growth. Available at http:// sloanconsortium.org/publications/survey/class_differences [Accessed 8 December 2020].

Almusharraf, N. M. \& Khahro, S. H. (2020). Students' satisfaction with online learning experiences during the COVID-19 pandemic. International Journal of Emerging Technologies in Learning (iJET), 15(21), pp. 246-267. DOI: 10.3991/ijet.v15i21.15647

Alqurashi, E. (2019). Predicting student satisfaction and perceived learning within online learning environments. Remote Education, 4O(1), pp. 133-148. DOI: 10.1080/01587919.2018.1553562

Anderson, T. (2003). Getting the mix right again: An updated and theoretical rationale for interaction. The International Review of Research in Open and Distributed Learning, 4(2), pp. 9-14. DOI: 10.19173/irrodl.v4i2.149

Babbie, E. (2013). The Practice of Social Research. $\left(13^{\text {th }}\right.$ ed.). Singapore: Wadsworth and Cengage Learning.

Basith, A., Rosmaiyadi, Triani, S.N. \& Fitri. (2020). Investigation of online learning satisfaction during COVID 19: In relation to academic achievement. Journal of Educational Science and Technology, 6(3), pp. 265-275. DOI:10.26858/est.v1i1.14803

Cahya, I. (2021). 10 Kota di Indonesia yang punya kecepatan Internet paling tinggi, kotamu masuk? [10 Cities in Indonesia that have the Highest Internet Speed, is your City in?]. Available at https://www.merdeka.com/teknologi/10-kota-di-indonesia-yang-punya-kecepatan-internetpaling-tinggi-kotamu-masuk.html [Accessed 16 July 2021].

Cassidy, S. \& Eachus, P. (2000). Learning style, academic belief systems, self-report student proficiency and academic achievement in higher education. Educational Psychology, 20(3), pp. 307-320. DOI: $10.1080 / 713663740$

Coman, C., Țîru, L. G., Meseșan-Schmitz, L., Stanciu, C. \& Bularca, M. C. (2020). Online teaching and learning in higher education during the coronavirus pandemic: Students' perspective. Sustainability, 12(24), pp. 1-24. DOI: 10.3390/su122410367.

Corfman, T. \& Beck. D. (2019). Case study of creativity in asynchronous online discussions. International Journal of Educational Technology in Higher Education, 16(22), pp. 1-20. DOI: 10.1186/s41239-019-0150-5

Croxton, R. A. (2014). The role of interactivity in student satisfaction and persistence in online learning. MERLOT Journal of Online Learning and Teaching, 10(2), pp. 314-325.

Dikti Kemendikbud. (2020). Buku Panduan Merdeka Belajar Kampus Merdeka. [A Guidebook to Independent Learning, Independent Campus]. Available at https://dikti.kemdikbud.go.id/ pengumuman/buku-panduan-merdeka-belajar-kampus-merdeka/. [Accessed 7 September 2021]. 
Du, Y. (2004). The relationship between students' computer competency and perception of enjoyment and difficulty level in web-based distance learning. Education Libraries, 27(2), pp. 5-12. DOI:10.26443/el.v27i2.201.

Dziuban, C., Graham, C.R., Moskal, P.D., Norberg, A. \& Sicilia, N. (2018). Blended learning: the new normal and emerging technologies. International Journal of Educational Technology in Higher Education, 15(3), pp. 1-16. DOI: 10.1186/s41239-017-0087-5

Dziuban, C. D., Hartman, J. L. \& Moskal, P. D. (2004). Blended Learning. Available at https://www. educause.edu/ /media/files/library/2004/3/erb0407-pdf.pdf?la=en [Accessed 7 September 2021].

Fatani, T.H. (2020). Student Satisfaction with Videoconferencing teaching Quality during the COVID-19 Pandemic. Medical Education, 20, 396, pp. 1-8. DOI:10.1186/s12909-020-02310-2

Firman, F. \& Rahman, S. R. (2020). Pembelajaran Online di Tengah Pandemi Covid-19 [Online Learning during the Covid-19 Pandemic]. Indonesian Journal of Educational Sciences (IJES), 2(2), pp. 81-89. DOI: 10.31605/ijes.v2i2.659

Foerderer, M., Hoffman, S., Schneider, N. \& Prichard, J. R. (2021). Predicting Levels of Student Satisfaction during COVID-19. Available at https://er.educause.edu/articles/2021/4/predictinglevels-of-student-satisfaction-during-covid-19 [Accessed 10 July 2021].

Fraenkel. J.R., Wallen, N. E. \& Hyun, H. H. (2012). How to Design and Evaluate Research in Education. New York: McGraw-Hill Publisher.

Garrison, D. R., Anderson, T. \& Archer, W. (2000). Critical inquiry in a text-based environment: Computer conferencing in higher education. The Internet and Higher Education, 2, pp. 87-105. DOI: 10.1016/S1096-7516(00)00016-6.

Giesbers, B., Rienties, B., Tempelaar, D. \& Gijselaers, W. (2013). A dynamic analysis of the interplay between asynchronous and synchronous communication in online learning: The impact of motivation. Journal of Computer Assisted Learning, 30(1), pp. 30-50. DOI: 10.1111/jcal.12020

Gopal, R., Singh, V. \& Aggarwal, A. (2021). Impact of Online Classes on the Satisfaction and Performance of Students during the Pandemic Period of COVID-19. Available at https://www. ncbi.nlm.nih.gov/pmc/articles/PMC8059127/ [Accessed 14 July 2021].

Gray, J. A. \& DiLoreto, M. (2016). The Effects of Student Engagement, Student Satisfaction, and Perceived Learning in Online Learning Environment. Available at: https://eric.ed.gov/?id=EJ1103654 [Accessed 16 August 2021].

Harasim, L. M. (1989). Online education: A new domain. In R. Mason \& A. Kaye (Eds.), Mindweave: Communication, Computers and Distance Education. New York: Pergamon Press, pp.50-62.

Hillman, D. C., Willis, D. J. \& Gunawardena, C. N. (1994). Learner-interface in remote education: An extension of contemporary models and strategies for practitioners. The American Journal of Remote Education, 8(2), pp. 30-42. DOI: 10.1080/08923649409526853

Iglesias-Pradas, S., Hernandes-Garcia, A. \& Chaparro-Pelaez, J. (2021). Emergency Remote teaching and students' academic performance in higher education during the COVID-19 pandemic: A case study. Computers in Human Behavior, 119, 106713, pp. 1-18. DOI: 10.1016/j.chb.2021.106713

Ivankova, N.V. \& Stick, S. L. (2007). Students' persistence in a distributed doctoral program in educational leadership in higher education: A mixed methods study. Research in Higher Education, 48(1), pp. 93-135. DOI: 10.1007/s11162-006-9025-4

Jaggars, S. S., Edgecombe, N. \& Stacey, G. W. (2013). Creating an Effective Online Instructor Presence. Available at http://files.eric.ed.gov/fulltext/ED542146.pdf [Accessed 7 September 2021].

Jamieson, S. (2005). Likert scales: how to (ab)use them. Medical Education, 38(12), pp. 1217-1218. DOI: 10.1111/j.1365-2929.2004.02012.x.

Jiang, H., Islam, A., Gu, X. \& Spector, J. M. (2021). Online learning satisfaction in higher education during the COVID-19 pandemic: A regional comparison between eastern and western Chinese universities. Education and Information Technologies, Advance online publication. DOI: 10.1007/ s10639-021-10519-x 
Jung, I., Choi, S., Lim, C. \& Leem, J. (2002). Effects of different types of interaction on learning achievement, satisfaction and participation in web-based instruction. Innovations in Education and Teaching International, 39(2), pp. 153-162. DOI: 10.1080/14703290252934603

Kemendikbud. (2020a). Pembelajaran secara Daring dan Bekerja dari Rumah untuk Mencegah Penyebaran Covid-19. [Minister of Education and Culture: Learning Online and Working from Home to Prevent the Spread of Covid-19]. Available at https://www.kemdikbud.go.id/main/ blog/2020/03/se-mendikbud-pembelajaran-secara-daring-dan-bekerja-dari-rumah-untukmencegah-penyebaran-covid19 [Accessed 20 May 2020].

Kemendikbud. (2020b). Bantuan Kuota Data Internet 2020 [Free Internet Data 2020]. Available at https://www.kemdikbud.go.id/main/blog/2020/09/kemendikbud-resmikan-kebijakanbantuan-kuota-data-internet-2020 [Accessed 16 October 2020].

Kemendikbud. (2021). Bantuan Kuota Data Internet 2021[Free Internet Data 2021]. Available at https://kuota-belajar.kemdikbud.go [Accessed 17 February 2021].

Kumar, V. \& Nanda, P. (2019). Social media in higher education: A framework for continuous engagement. International Journal of Information and Communication Technology Education (IJICTE), 15(1), pp. 109-120. DOI: 10.4018/IJICTE.2019010107

Kumar, P., Saxena, C. \& Baber, H. (2021). Leaner-content interaction in e-learning-the moderating role of perceived harm of COVID-19 in assessing the satisfaction of learners. Smart Learning Environments, 8(5), pp. 1-15. DOI: 10.1186/s40561-021-00149-8

Kuo, Y.C., Walker, A. E., Schroder, K. E. E. \& Belland, B. R. (2014). Interaction, internet self-efficacy, and self-regulated learning as predictors of student satisfaction in online education courses. The Internet and Higher Education, 20(1), pp. 35-50. DOI: 10.1016/j.iheduc.2013.10.001

Kusnayat, A., Muiz, M. H., Sumarni, N., Masyur, A. S. \& Zaqiah, Q. Y. (2020). Pengaruh teknologi pembelajaran kuliah online di era covid-19 dan dampaknya terhadap mental mahasiswa [The influence of online learning technology in the covid-19 era and its impact on student mental health]. EduTeach: Jurnal Edukasi dan Teknologi Pembelajaran, 1(2), pp. 153-165. DOI: 10.37859/eduteach.v1i2.1987

Lalima, K. \& Dangwal, L. (2017). Blended learning: An innovative approach. Universal Journal of Educational Research, 5(1), pp. 129-136. DOI: 10.13189/ujer.2017.050116

Lin, Y.M., Lin, G.Y. \& Laffey, J. M. (2008). Building a social and motivational framework for understanding satisfaction in online learning. Journal of Educational Computing Research, 38(1), pp. 1-27. DOI: 10.2190/EC.38.1.a

Loades, M. E., Chatburn, E., Higson-Sweeney, N., Reynolds, S., Shafran, R., Brigden, A., Linney, C., McManus, M. N., Borwick, C. \& Crawley, E. (2020). Rapid systematic review: The impact of social isolation and loneliness on the mental health of children and adolescents in the context of COVID-19. Journal of the American Academy of Child and Adolescent Psychiatry, 59(11), pp. 1218-1238. DOI: 10.1016/j.jaac.2020.05.009

Moore, M. G. (1989). Three types of interaction. The American Journal of Remote Education, 3(2), pp. 1-6. DOI: 10.1080/08923648909526659

Moore, M. G., \& Kearsley, G. (1996). Remote Education: A Systems View. Belmont, CA: Wadsworth.

Muzammil, M., Sutawijaya, A. \& Harsasi, M. (2020). Investigating student satisfaction in online learning: the role of student interaction and engagement in remote learning university. Turkish Online Journal of Remote Education, 21, pp. 88-96. DOI: 10.17718/tojde.770928

Ngo, J. \& Ngadiman, A. (2019). The impacts of Edmodo on students' performance in ESP classrooms in international seminar on language, education, and vulture. KnE Social Sciences, 3(10), pp. 369-378. DOI: 10.18502/kss.v3i10.3918

PDDikti Kemendikbud (2020). Higher Education Statistical Year Book 2020. Jakarta: Setditjen Dikti, Kemendikbud.

Shea, P., Li, C. S. \& Pickett, A. (2006). A study of teaching presence and student sense of learning community in fully online and web-enhanced college courses. The Internet and Higher Education, 9(3), pp. 175-190. DOI: 10.1016/j.iheduc.2006.06.005 
Sher, A. (2009). Assessing the relationship of student-instructor and student-student interaction to student learning and satisfaction in web-based online learning environment. Journal of Interactive Online Learning, 8(2), pp. 102-120.

Siahaan, M. (2020). Dampak pandemi covid-19 terhadap dunia pendidikan. [The impact of the covid-19 pandemic on the world of education]. Jurnal Kajian IImiah, 1(1), pp. 73 - 80. DOI: 10.31599/jki.v1i1.265

So, S. (2016). Mobile instant messaging support for teaching and learning in higher education. The Internet and Higher Education, 31, pp. 32-42. DOI: 10.1016/j.iheduc.2016.06.001

Speece, M. (2012). Learning style, culture and delivery mode in online distance education. US-China Education Review, 2(1), pp. 1-12.

Strachota, E. (2003). Student Satisfaction in Online Courses: An Analysis of the Impact of LearnerContent, Learner-Instructor, Learner-Learner and Learner-Technology Interaction. Unpublished doctoral dissertation, University of Wisconsin-Milwaukee. Ann Arbor, Michigan.

Strachota, E. (2006). The Use of Survey Research to Measure Student Satisfaction in Online Courses. Paper presented at the Midwest Research-to-Practice Conference in Adult, Continuing, and Community Education, University of Missouri-St. Louis, MO, 4-6 October.

Suryani, N. \& Sugianingrat, I. (2021). Student e-learning satisfaction during the Covid-19 pandemic in Bali, Indonesia. Jurnal Economia, 17(1), pp. 141-151. DOI: 10.21831/economia.v17i1.33196

Williams, E.A., Duray, R. \& Reddy, V. (2006). Teamwork orientation, group cohesiveness, and student learning: A study of the use of teams in online distance education. Journal of Management Education, 30(4), pp. 592-616. DOI: 10.1177/1052562905276740

World Bank (2021). Overview of Indonesia. Available at http://www.worldbank.org/en/country/ indonesia/overview [Accessed 7 July 2021].

Yukselturk, E., \& Yildirim, Z. (2008). Investigation of interaction, online support, course structure and flexibility as the contributing factors to students' satisfaction in an online certificate program. Educational Technology \& Society, 11(4), pp. 51-65. 
